\title{
Ekologi Tradisional Dayak Tamambaloh
}

\author{
Efriani $^{1}$, Jagad Aditya Dewantara ${ }^{2}$, Dewi Utami ${ }^{3}$, dan Indah Listyanigrum ${ }^{4}$
}

1Program Studi Antropologi, Universitas Tanjungpura; efriani@fisip.untan.ac.id

2Program Studi Pendidikan Pancasila dan Kewarganegaraan, Universitas Tanjungpura; jagad02@fkip.untan.ac.id

3Program Studi Ilmu Komunikasi, Universitas Tanjungpura; dewi.utami@fisip.untan.ac.id

4Program Studi Pembangunan Sosial, Universitas Tanjungpura; indah.listyaningrum@fisip.untan.ac.id

\begin{abstract}
ABSTRAK
Penduduk lokal khususnya yang tersebar di Nusantara memiliki beragam ekologi tradisional yang memiliki nilai-nilai konservatif. Di Kalimantan Barat, pada etnis Dayak Tamambaloh, terdapat fenomena pengelolaan lingkungan alam yang menjunjung nilai-nilai kelestarian. Mengkaji lebih dalam praktek ekologi tradisional Dayak Tamambaloh, menjadi tujuan utama penelitian ini. Data terkait praktek ekologi tradisional ini dikumpulan dengan wawancara mendalam, pengamatan lapangan dan studi dokumen. Tamanggung Tamambaloh, para petani, kelompok pengambil kebijakan dan pemangku adat Tamambaloh, ditentukan menjadi sumber informasi. Tindakan dalam pemanfaatan hutan dan isinya menjadi objek pengamatan. Beberapa buku terkait dengan profil ketamanggungan Tamambaloh, menjadi sumber informasi tertulis pada penelitian ini. Dari sejumlah data yang diperoleh di lapangan, ekologi tradisional Dayak Tamambaloh dapat dibagi dalam 4 kategori, yakni 1) pembagian kawasan adat berdasarkan peruntukannya, dan berdasarkan akses sumber daya, 2) Aturan akses sumber daya alam, 3) Proses pengambilan keputusan Pemanfaatan Sumber daya Alam, 4) Pengetahuan Gentika, dan 5) Kalender Musim. Kelima ekologi tradisional ini dapat direduksi ke dalam 4 model konservasi, yakni 1)Model Environmental Norms, 2) Model Proenvironmental Behavior dan Environmental Concern, 3)Model Community Involvemen, dan 4) Model enviromental Dicision
\end{abstract}

Kata kunci: Ekologi Tradisional, Konservasi Lingkungan, Norma Lingkungan, Peduli Lingkungan, Dayak Tamambaloh

\begin{abstract}
The Indigenous people, especially those scattered in the archipelago, has a variety of traditional ecologies that have conservative values. In West Kalimantan, the Dayak Tamambaloh ethnicity, there is a phenomenon of natural environmental management that upholds the importance of sustainability. Examining deeper into the traditional ecological practice of Dayak Tamambaloh is the main objective of this research. Data related to traditional ecological practices were collected through indepth interviews, field observations and document studies. Tamanggung Tamambaloh, peasants, policy-making groups and Tamambaloh customary stakeholders were determined to be sources of information. Actions in forest utilization and their contents are objects of observation. Several books related to the Tamambaloh profile are the source of written information on this research. From a number of data obtained in the field, the traditional ecology of Dayak Tamambaloh can be divided into four categories, namely 1) division of common areas based on their designation and based on access to resources, 2) rules of access to natural resources, 3) Decision-making processes for the Use of Natural Resources, 4)scientific knowledge, and 5) seasonal calendars. These five traditional ecologies can be reduced to 4 conservation models, namely 1 ) Environmental Norms Model, 2) Proenvironmental Behavior and Environmental Concern Model, 3) Community Involvement Mode, and 4) Environmental Dicision Model
\end{abstract}

Keywords: Traditional Ecology, Environmental Conservation, Environmental Norms, Environmental Concern, Dayak Tamambaloh

Citation: Efriani, Dewantara, J.A., Utami, D., dan Listyaningrum, I., (2020). Ekologi Tradisional Dayak Tamambaloh. Jurnal Ilmu Lingkungan, 18(3), 503-514, doi:10.14710/jil.18.3.503-514

\section{Pendahuluan}

Masyarakat adat Ketamanggung Tamambaloh melakukan perjuangan untuk menjaga lingkungan alam dari perkebunan sawit pada tahun 2007 hingga tahun 2013, kini Ketamanggung Tamambaloh menjadi 1 kecamatan di Kabupaten Kapuas Hulu yang tidak memiliki perkebunan sawit. Hal yang menarik lainnya ialah, sebagian besar zona konservasi Taman Nasional Betung Kerihun berada pada wilayah Ketamanggungan Tamambaloh. Pada Juli 2009 503 melalui surat keputusan Direkur Jenderal Perlindungan Hutan dan Konservasi Alam (Nomor SK. 120/IV-KK/ 2009 tanggal 15 Juli 2009) menetapkan Taman Nasional Betung Kerihun dalam 6 zona yakni zona inti, zona rimba, zona pemanfaatan, zona tradisional, zona religi, budaya dan sejarah serta zona khusus (Pemukiman). Berdasarkan zonasi tersebut, daerah aliran Sungai Tamambaloh seluas 120.343 ha (31.22\%) merupakan zona inti Taman Nasional Betung Kerihun yang keseluruhanya seluas 385.368 
ha. Seluas 59.806 ha $(25.83 \%)$ daerah aliran Tamambaloh masuk dalam zona rimba Taman Nasional Betung Kerihun yang keseluruhanya seluas 231.529 ha. Seluas 7.170 ha (28.84\%) Daerah aliran Sungai Tamambaloh masuk dalam zona pemanfaatan Taman Nasional Betung Kerihun yang luas keseluruhannya 24.859 ha. Seluas 28.250 ha (19.63\%) daerah aliran sungai Tamambaloh masuk dalam zona tradisional Taman Nasional Betung Kerihun yang keseluruhan luasnya 143.894 ha dan 4.182 ha $(41.01 \%)$ masuk dalam zona religi, budaya dan sejarah Taman Nasional Betung Kerihun yang seluruhnya seluas 10.196 ha (Taman Nasional Betung Kerihun, 2009).

Saat ini, Sungai Tamambaloh merupakan destinasi wisata yang berada di wilayah bagian Barat Taman Nasional Betung Kerihun. Sungai Tamambaloh menawarkan objek daya tarik serta menjadi jalur pertama bagi wisatawan untuk menikmati pesona alam kawasan Taman Nasional Betung Kerihun. Fenomena ini tentunya bukan hanya suatu fenomena sosial politik-ekonomi semata, namun di balik itu tentu hal ini menjadi suatu fenomena sosial budaya. Dalam kajiannya Efriani at al., menunjukkan adanya ikatan antara kosmologi Dayak Tamambaloh dengan tindakan konservasi lingkungan (Efrian et al., 2019).

Fenomena tindakan konservatif pada masyarakat lokal, bukan hanya terdapat pada Dayak Tamambaloh, namun juga telah menjadi fenomena di beberapa negara di dunia. Dalam hubunganya dengan lingkungan, masyarakat lokal telah menunjukan keberhasilannya dalam melestarikan Lingkungan (Agrawal, 2014; Al-Fattal, 2009; Barbieri \& Aguilar, 2011). Masyarakat Lokal di California dan Oregon menunjukan efektifitas manajemen lembaga lokal dalam pengelolaan perikanan (Al-Fattal, 2009); Tradisi Tongo pada penduduk lokal di Afrika Barat juga berhasil menjadi bentuk pengetahuan masyarakat adat melalui lembaga lokal dalam pengelolaan lingkungan yang berkelanjutan (Barbieri \& Aguilar, 2011); Chatla di distrik Cachar di Assam berhasil mengolah perikanan secara tradisianal (Laughlin, 2013); Masyarakat adat di Nepal berhasil mengelolah lingkungan secara tradisional (Wiersum, Singhal, \& Benneker, 2004); Lembaga adat di beberapa desa di India melalui kosmologi tradisonal juga berhasil dalam mengelola sumber air (Singh, 2006).

Di Indonesia, dalam hubunganya dengan lingkungan, masyarakat lokal telah menunjukan keberhasilannya dalam melestarikan lingkungan (Baharudin, 2012; Efriani et al., 2019; Siswadi et al., 2012). Di Kawasan Kars Gunung Kidul, para petani menggunakan cara konvesional yakni cara yang diwarisi secara turun-temurun dari nenek moyang mereka dalam mengelolah tanah pertanian dan irigasi. Tradisi ini menjadikan mereka sebagai petani yang arif terhadap lingkungan (Baharudin, 2012). Etnis Dayak, secara tradisional telah menunjukkan pengelolaan yang bersifat konservatif (Efriani et al., 2019; Seftyono, 2011; Setyawan, 2010; Siahaya et al.,
2016). Selain pengetahuan ekologi tadisional masyarakat lokal juga memiliki lembaga-lembaga khusus dalam pengelolaan lingkungan (Yuliani et al., 2018). Fenomena ini sejalan dengan pernyataan bahwa penduduk pribumi dalam interaksi timbal balik dengan lingkungannya, selain dipengaruhi oleh sistem kepercayaan tetapi juga dipengaruhi oleh sistem pengetahuan lokal mereka (Iskandar Johan, 2012).

Perserikatan Bangsa-Bangsa (PBB) telah menjadi forum utama yang mengakui dan melindungai hakhak masyarakat lokal dalam pengelolaan alam. Melalui deklarasi tentang hak-hak masyarakat adat (Draft Declaration on the Rights of Indigenous Peoples), PBB memberikan penekanan pada pentingnya sistem pengetahuan adat dan lokal, yang dipandang sebagai pusat integritas dan kesejahteraan masyarakat adat (Ford et al., 2020). Sehinga tidak mengherankan jika pengelolaan sumber daya secara komunal menjadi satu jawaban bagi pengelolaan lingkungan yang berkelanjautan (Sick, 2008). Bromley and Cernea (1989) menyebut fenomena ini dengan istilah common property regime, yakni kepemilikan oleh sekelompok orang tertentu dimana hak, kewajiban dan aturan ditetapkan dan berlaku untuk anggota kelompok tersebut (Bromley \& Cernea, 1989).

Fenomena-fenomena lingkungan yang berkelanjutan pada komunitas lokal, erat kaitannya dengan ekologi tradisonal pada masyarakat lokal. Masyarakat Lokal menjadi aktor yang berperan aktif dalam pengelolaan sumber daya alam di sekitarnya (Iskandar \& Iskandar, 2016; Uprety et al., 2012). Kajian yang kompleks tentang hubungan manusia dengan alam merupakan pemahaman akan Corpuscosmos-Praxis (Iskandar Johan, 2012). Corpuscosmos-praxis yakni perilaku praktik (Praxis) penduduk pribumi atau penduduk tradisional dalam memanfaatkan sumber daya alam atau keanekaragaman hayati, biasanya dipengaruhi oleh sistem pengetahuan (Corpus), serta pemahaman manusia tentang alam dan kepercayaan (Cosmos).

Uraian di atas memberikan landasan akan pentingnya peran masyarakat lokal dalam pelestarian lingkungan. Belajar dan mengkaji kearifan lingkungan pada masyarakat lokal menjadi suatu kajian yang menarik dan penting. Fenomena kelestarian lingkungan pada komunitas adat, terutama Dayak Tamambaloh, menjadi tujuan dari kajian ini. Kajian ini dimaksudkan untuk menggali lebih dalam, hal-hal yang dilakukan oleh Dayak Tamambaloh dalam melestarikan lingkungan alam Tamambaloh. Kajian ini dimaksudkan untuk mendeskripsikan pengetahuan ekologi tradisional Dayak Tamambaloh sebagai satu model konservasi lingkungan.

\section{Metode}

Dayak Tamambaloh merupakan satu etnik Dayak yang mendiami sepanjang sungai Tamambaloh di Kabupaten Kapuas Hulu, Kalimantan Barat. Ekologi tradisional dan tindakan pengelolaan dan 
pemanfaatan lingkungan alam etnik ini menjadi objek kajian penelitian ini. Dengan teknik porpuseful sampling, Tamanggung Tamambaloh menjadi informan utama pada penelitian ini. Wawancara mendalam dilakukan kepada 3 kelompok masyarakat yang terdiri dari petani (penggarap hutan dengan ladang berpindah), ketua adat tingkat dusun dan para pengambil kebijakan (staf pemerintahan tingkat desa) untuk mendapatkan data terkait pengelolaan dan akses sumber daya alam pada Dayak Tamambaloh. Selain wawancaa, guna mentriangulasi informasi, penulis juga melakukan pengamatan terhadap caracara orang dayak Tamambaloh dalam "mengambil" sumber daya untuk keperluan sehari-hari. Studi dokumen juga dilakukan terhadap beberapa buku, diantaranya, buku profil ketamanggungan Tamambaloh dan Profil Taman Nasional Betuang Kerihun (TNBK).

Analisis data pada penelitian ini dilakukan bersamaan dengan pengumpulan data. Data-data yang dikumpulkan di kelompokkan berdasarkan kategori ekologi tadisional Dayak Tamambaloh, kemudian direduksi ke dalam beberapa model konservasi lingkungan untuk penarikan kesimpulan.

\section{Hasil dan Pembahasan}

\subsection{Ekologi Tradisional Dayak Tamambaloh}

Ekologi tradisional merupakan pengetahuan tentang lingkungan yang berkembang dalam keseharian masyarakat lokal (Berkes, 1993; Efriani et al., 2019; Iskandar \& Iskandar, 2016; Messalina et al., 2017; Seftyono, 2011). Pada umumnya pengetahuan tentang alam yang terdapat dalam masyarakat lokal sering disebut local knowledge (Posey, 2005), traditional knowledge (Uprety et al., 2012) pengetahuan ekologi tradisional (Traditional Ecological Knowledge-TEK) (Boafo et al., 2016; Siahaya et al., 2016), Kearifan lokal (traditional wisdom) (Aziz Nasihuddin, 2017; Kakoty, 2018) atau local ecological knowledge (Anbleyth-Evans at al., 2020). Belum ditemukan kesepakatan di antara para ahli tentang istilah pengetahuan lokal atau pengetahuan ekologi lokal tersebut (Iskandar, 2012). Dalam tulisan ini, pengetahuan Ekologi Tradisional, mengacuh pada istilah Traditional Ecological Knowledge (TEK).

Posey menyebutkan bahwa Pengetahuan Tradisional Ekologis (TEK) merupakan pengetahuan tradisional, inovasi dan praktek-praktek pada masyarakat adat dan lokal terwujud dalam gaya hidup tradisional. Lebih lanjut Posey menjelaskan pengetahuan ekologi tradisional (TEK) merupakan suatu yang holistik, dinamik, dan terus berkembang melalui eksperimen, inovasi, dan rangsangan eksternal (Posey, 2005). Pengetahuan ekologi tradisional ini, semakin disadari manfaatnya oleh para ilmuan dan para pemangku kepentingan kenegaraan, khususnya dalam pengelolaan alam.

Pengakuan akan integritas ekologi tradisional bersamaan dengan pengakuan akan masyarakat yang dikelompokkan sebagai masyarakat lokal. Masyarakat lokal umumnya disamakan dengan istilah 'indigenous'(Ferrante, Gomes, \& Fearnside, 2020; Ford et al., 2020). Kalland dengan mengutip pernyataan Gray (1995) dan Kingsbury (1995)(Kalland, 2005) menjelaskan 'indigenous' dalam arti luas-sering digunakan bergantian dengan kata 'pribumi' dan 'aboriginal'-terkait dengan penduduk pertama yang diketahui atau penduduk asli, dan lebih sempit, istilah ini menunjukkan pada suku-suku kecil keturunan non-Eropa (Kalland, 2005). John A. Grim menjelaskan bahwa "masyarakat adat atau masyarakat lokal", merujuk pada kelompok etnis dengan ikatan budaya, bahasa, dan kekeluargaan yang jelas, yang sering terpinggirkan oleh bangsa modern, dan berada dalam bahaya hilang (Grim, 2001). Kalland, menjelaskan bahwa saat ini konsep masyarakat lokal, penduduk pribumi, masyarakat adat, dan konsep-konsep lainnya cenderung digunakan oleh masyarakat lokal sendiri dalam rangka mengumpulkan dukungan bagi perjuangan mereka untuk mendapatkan pengakuan sebagai kelompok masyarakat yang memiliki budaya sendiri dan hak untuk menentukan nasib sendiri (Kalland, 2005:318).

Berdasarkan uraian tentang masyarakat lokal, Dayak Tamambaloh termasuk kategori sebagai masyarakat lokal yang disebut dengan istilah indigenous peoples. Dayak Tamambaloh adalah komunitas pribumi, salah satu etnis Dayak yang diikat oleh satu budaya, bahasa dan kekeluargaan (Efriani et al., 2019). Dayak Tamambaloh adalah pribumi yang menempati bagian Barat pulau Borneo. Dayak Tamambaloh telah ada di Tanah Tamambaloh sebelum bangsa Eropa yang dipelopori oleh misionaris Gereja Katolik yakni Ordo Kapusin pada akhir abad ke-18 tiba di Kapuas Hulu(Paroki Santo Martinus, 2013). Jauh sebelum ekspansi bangsa Eropa, Dayak Tamambaloh berkeyakinan telah mendiami Tamambaloh, walaupun tidak ditemukan kapan waktunya nenek moyang Dayak Tamambaloh ada di Tanah yang kini dinamai ketamanggungan Tamambaloh tersebut (Efriani, et.al 2019).

Dayak Tamambaloh, memiliki hubungan yang sangat erat dengan lingkungan alam sekitarnya. Hubungan Dayak Tamambaloh tampak dalam penyebutan dan penamaan suku ini yang diadopsi dari pola ketergantungan dan kekaguman suku ini terhadap alam sekitarnya. Pada wawancara yang dilakukan terhadap Tamanggung Tamambaloh, disebutkan bahwa nama Suku ini merupakan ungkapan kekaguman suku ini akan kelimpahan sumber daya alam di sekelilingnya.

Dalam sejarah penamaanya, suku Dayak Tamambaloh merupakan sub suku Dayak Kalimantan Barat, dan penamaan etnik ini diambil dari sungai Tamambaloh. Tamambaloh berasal dari kata setempat yakni "Taumamlalo" yang berarti orang yang kaya. Kata Taumamlalo yang berarti "kaya" merupakan ungkapan kekaguman akan situasi dan 
kondisi daerah aliran Sungai Tamambaloh yang kaya dengan tumbuhan dan hewan, tanah yang subur, sayuran, buah-buahan dan berbagai jenis hewan yang dapat menjadi bahan sandang. Nenek moyang kami bertani dan berburu di sekitar bantaran Sungai Tamambaloh. Berkelimpahan hasil panen padi, sehingga mereka menyebut diri mereka "Taumamlalo" atau orang kaya. Kekayaan yang maksud bukanlah harta benda, melainkan merujuk pada kelimpahan padi yang dipanen. Hingga kini, etnis kami disebut etnis Dayak Tamambaloh, tinggal di sepanjang bantaran Sungai Tamambaloh, mata pencaharian mengolah alam dengan berladang berpindah.

Mata pencaharian ladang berpindah, menjadikan Dayak Tamambaloh menggantungkan hidupnya pada sumber daya alam di sekitarnya. Kedekatan dengan alam sekitar menjadikan mereka memiliki ekologi sebagai bentuk pengetahuan tradisional. Ekologi tadisional ini pertama-tama karena masyarakat adat memiliki pengetahuan empiris yang luas tentang lingkungan mereka. Kedua, mereka menawarkan interpretasi dari pengetahuan empiris secara radikal berbeda dari paradigma ilmiah konvensional. Ekologi tradisional merupakan sekumpulan pengetahuan, praktik, dan keyakinan, berkembang melalui proses adaptif dan turun temurun ditransmisikan melalui budaya, berisi tentang hubungan makhluk hidup (termasuk manusia) dengan sesama dan dengan lingkungan mereka (Berkes, 2008; Daeng, 2008).

Di Indonesia, upaya konservasi alam dalam pengetahuan ekologi tradisional ini, telah cukup lama dikenal dan dipraktikan (Abdoellah, 2012). Pengetahuan ekologi lokal ini, memandang alam bukan sebagai "sumber daya semata" (ekonomi dan politik) namun memiliki nilai-nilai budaya dan kehidupan (Suradisastra, 2011). Nilai-nilai ekologis sebagai bagian dari kebudayaan dan kehidupan inilah yang memiliki dampak positif terhadap keberlanjutannya sumber daya alam. Berdasarkan prinsip-prinsip hubungan manusia dengan alam, dapat ditemukan beberapa bentuk ekologi tradisional Dayak tamambaloh dalam hubunganya dengan kelestarian alam Tamambaloh. Ekologi tradisional itu berupa 1) Pembagian kawasan adat berdasarkan peruntukannya, dan berdasarkan akses sumber daya, 2) Aturan akses sumber daya alam, 3) Proses pengambilan keputusan Pemanfaatan Sumber daya Alam, 4) Pengetahuan Gentika, dan 5) Kalender Musim.

\section{1)Pembagian Kawasan Ketamanggungan Tamambaloh Berdasarkan Peruntukannya dan Berdasarkan Akses Sumber Daya}

Pada umumnya, etnis-etnis di Indonesia, mengenal pola pembagian kawasan, yang didasarkan pada konsepsi sistem kepercayaan. Diantaranya, pemukiman Kajang di Sulawesi Selatan yang terdiri dari beberapa situs yang dibagi berdasarkan fungsinya (Erawati, 2016). Masyarakat desa adat Bali Aga juga mengenal pola pengaturan kawasan yang didasarkan para falsafah Tri Hita Karana (THK) yang menjadi tata kelola sumber daya (Sumunar, Suparmini, \& Setyawati, 2017). Pada masyarakat kasepuhan di Jawa Barat juga terdapat pembagian hutan berdasarkan fungsinya, menjadi Hutan Titipan, Hutan Tutupan, dan Hutan Garapan (Rusmana et al., 2017). Fenomena ini juga terdapat pada Dayak Tamambaloh. Dayak Tamambaloh memiliki sistem pembagian kawasan ketamanggungan Tamambaloh. Perlu kami tekankan, bahwa pembagian kawasan dilakukan secara berjenjang menurut peruntukkanya dan tidak memiliki hubungan secara langsung dengan bentuk dan struktur sosial Dayak Tamambaloh yang dibagi dalam 3 kelompok secara bertingkat, yakni Kaum Samagat, Kaum Pabiring dan Kaum Suang Sao. Dalam akses sumber daya, ketiga tingkat status sosial ini memiliki hak dan kewajiaban yang sama, bahkan terhadap sanksi atas pelanggaran dalam akses sumber daya ala, Tamambaloh.

Berdasarkan studi lapangan dan pengkajian dokumentasi terkait pengelolaan lingkungan, Dayak Tamambaloh memiliki pembagian kawasan ditetapkan secara berjenjang menurut manfaat atau peruntukannya, yakni kawasan hutan yang dilindungi, kawasan hutan produksi dan kawasan kampung dan pemukiman warga.

\section{a. Kawasan Adat yang Dilindungi (Toan Palalo)}

Kawasan adat yang dilindungai merupakan kawasan yang ada diperhuluan Sungai Tamambaloh, sungai Tamao, Sungai Apan, Sungai Unga', Sungai Pulan, Sungai Utik, Sungai Timbaru, dan Sungai Alau'. Kawasan lindung ini berfungsi untuk menjaga keseimbangan ekosistem, sumber daya air, dan sebagai persediaan untuk kehidupan masyarakat adat dimasa yang akan datang. Kawasan adat ini telah ditetapkan oleh pemerintah dan badan dunia sebagai lahan konservasi Taman Nasional Betung Kerihun Daerah Aliran Sungai Tamambaloh (DAS Tamambaloh). Pemeliharaan dan pengelolaan kawasan lindung ini dilakukan secara bersama-sama antara komunitas adat dengan badan pengelola Taman Nasional Betung Kerihun (TNBK) dengan prinsip saling terbuka dan setara.

Adapun batas-batas kawasan adat yang dilindungi ini, pada bagian Utara berbatasan langsung dengan Negara Sarawak Malaysia di Bukit Makop, Bukit Batik dan Tinting Lubang Ribut menuju ke arah Timur berbatasan dengan Kecamatan Embaloh Hilir. Pada bagian Utara, Kawasan lindung ini, menjadi satu kesatuan dengan kawasan perlindungan Alam Lanjak Entimau di Sarawak Malaysia. Pada bagian Selatan, berbatasan dengan kawasan inti jalur pintu masuk Daerah Aliran Sungai (DAS) Tamambaloh mulai titik sentral di Barat yakni di Bukit Betung dan kawasan Bukit Betung di hulu Sungai Binalik Pontol, menuju Sungai Tukalan di sekitar Wong Naris kawasan kaki dan puncak Bukit Condong terus ke hamparan pertengahan Sungai Peang yaitu (Batu Bukit) hulu Sungai Peang sampai ke Nanga Peang memotong ke arah Timur sampai batas Kecamatan Embaloh hilir. Kawasan yang dilindung ini juga termasuk hutan 
penyangga yang terdapat di daerah Aliran Sungai Tamambaloh yaitu di Nanga Sungai Palo yang meliputi daerah aliran anak sungai: Sungai Tamao, Sungai Apan, Sungai Pulan, Sungai Utik, Sungai Timbaru, dan Sungai Alau.

\section{b. Kawasan Adat Produksi}

Kawasan adat yang diperuntukkan sebagai kawasan produksi merupakan kawasan yang dapat dikelola sebagai sumber produksi masyarakat dengan memanfaatkan potensi-potensi alam di dalamnya. Kawasan adat ini merupakan kawasan adat yang disediakan untuk kegiatan eksploitasi oleh badan usaha yang memenuhi syarat dengan prinsip kerjasama saling menguntungkan secara seimbang, terang dan adil. Adapun batas-batas kawasan produksi ini, Daerah Aliran Sungai Tamambaloh yaitu mulai dari batas dengan Taman Nasional Betung Kerihun di Nanga Sungai Palo mengalir ke Hilir sampai batas Temanggung Iban Batu Peti. Di jalur aliran anak sungai lain (Tamao, Apan, Unga, Timbari, Pulan, Sungai Utik dan Sungai Alau) mengakui rentang batas kawasan adat yang dilindungi sampai batas adat kampung. Kawasan adat produksi ini umumnya digunakan sebagai lahan pertanian dan perkebunan. Lahan produksi ini lebih banyak digunakan dan dikelola secara pribadi oleh masyarakat Tamambaloh dan sebagian besar bekerjasama dengan pemerintah, seperti perkebunan karet, koko, dan gaharu.

\section{c. Kawasan Pemukiman}

Kawasan Pemukiman, merupakan kawasan yang dimiliki dan hak kelola masyarakat adat masingmasing kampung. Batas kawasan adat kampung ini penetapannya di atur oleh mayarakat adat masingmasing kampung bersama kampung tetangga dengan prinsip musyawara mufakat yang disemangati paham kekeluargaan di hadapan para fungsionaris adat dan let-let adat atau staf adat dusun dan desa.

\section{d. Kawasan Ketamanggungan Tamambaloh Berdasarkan Akses Sumber Daya}

Pembagian ruang kelola alam merupakan pengetahuan ekologi Dayak Tamambaloh yang telah disepakati bersama. Berikut pembagian ruang berdasarkan karakteristik alam oleh Dayak Tamambaloh.

Tabel 1. Kawasan dan Peruntukannya

\begin{tabular}{|c|c|c|}
\hline No & Kawasan & Peruntukan \\
\hline 1. & Toan langke & $\begin{array}{l}\text { Hutan yang masih rimbun, luas dan jarang dijelajahi oleh manusia dan di hutan ini umumnya merupakan } \\
\text { habitat berbagai jenis hewan dan tumbuhan. }\end{array}$ \\
\hline 2. & Toan Jajab & $\begin{array}{l}\text { Hutan yang berawa dan tidak ditumbuhi oleh kayu-kayu besar, karena hutan tersebut ditumbuhi lumut, kayu- } \\
\text { kayuan kecil yang padat. Pada umunya dapat ditemukan rotan dan kantong semar. }\end{array}$ \\
\hline 3. & Toan Karapa & $\begin{array}{l}\text { Hutan yang berawa, biasanya digunakan sebagai tempat mengambil rotan, damar, obat-obatan, bahan } \\
\text { bangunan dan tempat berburu }\end{array}$ \\
\hline 4. & Toan Karangas & $\begin{array}{l}\text { Dataran tinggi yakni hutan yang tidak bisa digunakan sebagai lokasi perladangan karena tanahnya berpasir } \\
\text { dan berdebu. }\end{array}$ \\
\hline 5. & Toan Karangas & $\begin{array}{l}\text { Dataran rendah yakni hutan yang jenis tanahnya kurang subur dan ditumbuhi oleh jenis kayu tertentu seperti } \\
\text { meranti, resak, kelasau, digunakan sebagai tempat pencarian bahan bangunan. }\end{array}$ \\
\hline 6. & Pangarang & $\begin{array}{l}\text { Bekas ladang yang pernah digarap oleh masyarakat untuk berladang dan setelah itu ditinggalkan dalam } \\
\text { jangka waktu kurang lebih }>30 \text { tahun dan akhirnya ditumbuhi kayu-kayu besar, lahan ini memiliki pewaris. }\end{array}$ \\
\hline 7. & Pareoan & $\begin{array}{l}\text { Lahan yang boleh digarap untuk berladang, berkebun dan mengumpulkan bahan bangunan, berburu, lahan } \\
\text { ini umumnya dekat dengan pemukiman penduduk. }\end{array}$ \\
\hline 8. & Belean uma & $\begin{array}{l}\text { Bekas ladang yang sudah ditinggalkan, umumnya, dimanfaatkan kembali sebagai tempat berkebun sayur dan } \\
\text { buah atau diolah kembali untuk ladang, ada juga yang dijadikan kebun karet atau koko. }\end{array}$ \\
\hline 9. & Uma yakni & Ladang masyarakat yang ditanami padi, dan ladang ini digarap dalam satu tahun. \\
\hline 10. & Kobon & $\begin{array}{l}\text { Lahan yang ditanami berbagai jenis tanaman seperti karet, tengkawang, kopi, koko, durian dan buah-buahan } \\
\text { yang bersifat musiman }\end{array}$ \\
\hline 11. & Banua & Tempat bermukim atau tempat tinggal penduduk atau perkampungan. \\
\hline 12. & Belean sao & $\begin{array}{l}\text { Bekas pemukiman penduduk yang ditinggalkan dengan alasan tertentu seperti bencana alam dan sebagainya } \\
\text { dan terdapat tanaman buah-buahan. }\end{array}$ \\
\hline 13. & Sunge Baraa & $\begin{array}{l}\text { Sungai besar yang digunakan sebagai jalur transfortasi dan semua muara sungai kecil bermuara di sungai } \\
\text { besar ini, Sungai Tamambaloh. }\end{array}$ \\
\hline 14. & Sunge keke & $\begin{array}{l}\text { Sungai kecil digunakan sebagai tempat mencari ikan dengan memancing, pukat, bubu dan alat tradisional } \\
\text { lainnya. }\end{array}$ \\
\hline 15. & Kokoan & $\begin{array}{l}\text { Sungai besar Tamambaloh yang terputus dan menjadi danau yang tidak bisa kering, pada umumnya } \\
\text { digunakan sebagai tempat mencari ikan. }\end{array}$ \\
\hline 16. & Kakaringan & $\begin{array}{l}\text { Danau kecil yang terbentuk secara alami dan apabila musim kemarau akan kering, merupakan tempat } \\
\text { mencari ikan dengan cara memancing, pukat, jala dan alat tradisional lainnya. }\end{array}$ \\
\hline 17. & Ulak & $\begin{array}{l}\text { Bagian sungai yang lebih besar dan dalam (lubuk) yang digunakan oleh sebagai tempat mencari ikan dengan } \\
\text { cara memancing. }\end{array}$ \\
\hline 18. & Lalo & $\begin{array}{l}\text { Pohon kayu yang tinggi dan besar, tempat bersarangnya lebah penghasil madu. Kayu ini, sengaja dibiarkan } \\
\text { tinggi dan tidak akan pernah ditebang. }\end{array}$ \\
\hline 19. & Kulambu & Kawasan perkuburan. \\
\hline
\end{tabular}

Dari pengamatan dan wawancara yang dilakukan terhadap Tamanggung Tamambaloh, dapat disimpulkan bahwa pembagian kawasan dan juga pemberian nama berdasarkan kategori dari sumber daya tersebut. Kawasan yang dikategorikan sebagai kawasan yang dilindungi ialah daerah-daerah perhuluan sungai. Kawasan-kawasan tersebut disebut sebagai kawasan penyanggah. Bagi Dayak 
Tamambaloh, sungai memiliki arti yang sangat vital dalam kehidupan mereka. Sebagian sumber pangan mereka peroleh dari sungai, seperti ikan, udang, dan beberapa bahan lauk lainnya. Selain itu, Dayak Tamambaloh menggunakan sungai sebagai sumber air minum dan untuk mandi.

Penamaan dan pembagian ruang alam yang didasarkan pada karakteristiknya tersebut, merupakan pengetahuan kolektif Dayak Tamambaloh. Pengetahuan dan pembagian ruang ini, menentukan tindakan mereka dalam pemanfaatan hutan, ruang dengan karakteristik tertentu boleh dikelola manusia, dan ruang yang lainnya wajib disimpan atau dijaga. Pengetahuan dalam bentuk pembagian ruang ini, menjadi alat kontrol bagi mereka dalam mengelola alam. Mereka dengan sengaja membiarkan Toan Palalo atau hutan yang tidak boleh diolah sebagai lahan pertanian atau perkebunan. Toan Palalo merupakan hutan rimba yang mencakup toan langke, toan jajab, Toan Karapa, Toan Karangas, Toan Karangan yang pengelolaannya hanya dengan mengambil sumber daya seperti rotan, damar, bahan bangunan, obat-obat serta tempat untuk berburu. Toan Palalo tidak diperkenankan untuk dieksploitasi.

\section{2) Aturan Akses Sumber Daya Alam}

Di beberapa etnis di Indonesia, terdapat lembagalembaga tradisional yang secara khusus menjadi lembaga pengelolaan sumber daya. Di antaranya sistem sasi di Maluku (Patriana et al., 2016) di dalamnya terdapat aturan askses sumber daya, berupa larangan atau tabu selama periode tertentu untuk mengakses sumber daya tertentu pula. Pada masyarakat Mandailing Natal di Sumatera Utara, terdapat aturan dalam Pengelolaan, pemanfaatan, pelestarian hutan, tanah dan sungai berupa aturan tertulis (uhum) (Nurani, 2015). Pada Dayak Tamambaloh juga terdapat aturan pengelolaan sumber daya alam, terutama terkait dengan sanksi atas larangan akses. Pengelolaan ruang alam Tamambaloh terbagai dalam dua bentuk, yakni ruang yang dimiliki secara perorangan atau kelompok (ruang yang diwariskan) dan ruang yang dikelola dan dimiliki oleh seluruh Dayak Tamambaloh. Pemanfaatan ruang alam tersebut dilindungi dalam adat Tamambaloh yang berkaitan dengan pengelolaan wilayah dan sumber daya alam Tamambaloh.

Pada buku Profil Wilayah Adat Ketemanggungan Tamambaloh dan Ketemanggungan Iban Menua Sadap 2013 disampaikan aturan-aturan tertulis tentang pengelolaan wilayah yang merupakan hak waris atau ruang yang dimiliki secara perorangan atau kelompok ialah berikut:

(1) Barang siapa mematok, memberi tanda (maundami) tanah milik orang lain dengan melanggar ketentuan adat, maka dikenakan sanksi adat berupa 2 kaletau amas dan saut 1 ekor ayam dan tanah dikembalikan kepada pemiliknya.

(2) Barang siapa dengan sengaja dan tanpa seizin pemilik, menggarap tanah perkebunan, ladang atau persawahan milik orang lain maka dikenakan sanksi adat berupa 4 kaletau emas dan saut 1 ekor ayam serta membagi 2 hasil bersih (setelah dipotong biaya kerja dan lain-lainnya) yang didapatkan dari tanah tersebut.

(3) Barang siapa dengan sengaja dan tanpa izin pemilik, menggarap tanah perkebunan, ladang atau persawahan yang merupakan warisan hak milik bersama ahli waris, maka dikenakan sanksi adat berupa 2 kaletau amas dan 1 ekor ayam sebagai saut serta membagi 2 hasil dari lahan tersebut.

(4) Barang siapa yang dengan sengaja memindahkan atau menghilangkan dan membuat batas tanah tersebut menjadi tidak jelas, dengan maksud dan tujuan memperluas tanah miliknya dengan memiliki sebagian besar atau sebagian kecil tanah milik orang lain, maka dikenakan sanksi adat berupa 4 kaletau amas dan 1 ekor ayam serta mengembalikan batas tanah pada tempat semula.

(5) Barang siapa yang dengan sengaja tanpa persetujuan ahli waris menjual tanah milik bersama, maka dikenakan sanksi adat berupa 2 kaletau amas dan 1 ekor ayam sebagai saut serta mengembalikan tanah tersebut.

Adapun aturan adat Tamambaloh berkaitan dengan pengelolaan sumber daya alam milik bersama, seperti berikut ini:

(1) Barang siapa dengan sengaja menuba atau meracun ikan di sungai dengan zat kimia atau melakukan penyentruman ikan di sungai atau di danau dikenakan sanksi adat 8 kaletau amas dan 1 ekor saut babi serta mengganti biaya pemulihan lingkungan dan kerusakan yang ditimbulkan akibat tindakan tersebut, serta dilakukan penyitaan alat-alat yang digunakan untuk selanjutnya diserahkan kepada pihak yang berwajib untuk diproses dan dihukum sesuai aturan yang berlaku.

Apabila tindakan merusak lingkungan dengan zatzat kimia menimbulkan korban jiwa (mengganggu kesehatan penduduk bahkan menyebabkan kematian) maka dikenakan sanksi pati nyawa secara penuh dan mengganti biaya pemulihan lingkungan serta akan diserahkan kepada pihak yang berwajib untuk selanjutnya diproses sesuai peraturan yang berlaku.

(2) Barang siapa yang dengan sengaja mengambil atau menebang pohon di area toan Palalo (hutan yang dilindungi), maka dikenakan sanksi adat berupa 6 kaletau amas, 1 ekor babi saut dan membayar ganti rugi, untuk kayu dengan diameter $30-60 \mathrm{~cm}$ akan diganti dengan uang Rp400.000,-/M² ditambah Rp60.000 per pohon.

Pengaturan akses sumber daya pada Dayak Tamambaloh ini, memiliki nilai-nilai konservasi ekologi. Bahkan jangkauan dari peraturan ini,

1 Kaletau amas sama dengan 6 gram emas murni 24 karat ditambah 15 gram emas biasa, dan satuannya dalam Rupiah disesuaikan dengan harga emas yang berlaku pada saat itu. 
bukan hanya anggota ketamanggungan Dayak Tamambaloh, namun berlaku juga bagi siapapun yang mengases sumber daya Katamanggungan Tamambaloh. Dalam wawancara dengan Tamanggung Tamambaloh, diungkapkan bahwa sanksi adat dan aturan tetang akses sumber daya ini merupakan kesepakatan seluruh warga Ketamanggungan Tamambaloh dan berlaku bagi siapapun termasuk, orang di luar Katamanggungan. Dalam penuturanya, aturan ini, berlaku hingga saat ini, dan sangat efektif dalam mendukung konsep kelestaraian lingkungan.

\section{3) Pantang Larang dalam Pemanfaatan Sumber Daya Alam Tamambaloh}

Setiap masyarakat mengembangkan teknik dan proses pengambilan keputusan dalam pemanfaatan lingkungan dengan didasarkan pada faktor ilmiah, sosial dan budaya. Ilmu pengetahuan, teknologi, ekonomi, politik, opini publik, dan nilai-nilai budaya semuanya berperan dalam proses pengambilan keputusan. Pengambilan keputusan tetang pemanfaatan lingkungan tentunya berorientasi pada sumber daya yang dimiliki secara bersama, nilai-nilai yang terkandung dalam suatu sumber daya dan juga pertimbangan lingkungan yang keberlanjutan (Docherty, 2016). Tiap-tiap masyarakat telah memiliki dan mengembangkan beberapa bentuk dan alat dalam pengambilan keputusan dalam pemnafaatan sumber daya alam.

Mengacu pada konsep pengelolaan sumberdaya alam yang dikemukakan oleh Bromley and Cernea (1989), pemanfaatan sumber daya alam pada etnis Dayak Tamambaloh, dilakukan secara komunal (Commons Property). Sumber daya alam dipandang sebagai milik bersama (collective goods), sehingga proses pengambilan keputusan (making dicisions) dalam pemanfaatan sumberdaya alam berbasiskan pada mekanisme yang telah dimiliki oleh etnis ini, secara turun temurun. Pengambilan keputusan dalam pemanfaatan sumber daya alam Tamambaloh dilakukan dengan mengacuh pada pantang-larang atau tradisi yang erat kaitanya dengan kosmologi (Efriani et al., 2019). Oleh karenanya, Mereka melakukan berbagai ritual untuk memulai membuka ladang, ataupun menebang pohon untuk bangunan rumah.

Bagi mereka, tanah, sungai, pohon, dan hewanhewan harus dihargai dalam berbagai ritual. Manusia tidak dengan leluasa melakukan pengambilan kayu, pemanfaatan tanah, namun harus melalui proses yang panjang. Secara ilmiah, tindakan-tindakan tersebut merupakan tindakan yang irasional. Pohon atau kayu, tanah dan air merupakan sumber daya alam yang dapat diambil, dipakai manusia, tanpa adanya proses yang disebut meminta izin kepada hantu-hantu ataupun roh-roh leluhur. Hutan, tanah, air, udara, adalah sumber daya yang wajib dimanfaatkan oleh manusia untuk menjaga kelangsungan hidupnya. Pantang dan ritual dalam pemanfaatan hutan dan tanah oleh Dayak Tamambaloh, merupakan alat adaptasi mereka dengan lingkungan sekitar mereka. Melalui berbagai ritual dan pantangan tersebut, Dayak Tamambaloh dapat survive karena mereka berhasil dalam memanfaatkan lingkungan.

Dengan demikian, tampak bahwa pengambilan keputusan dalam pengelolaan sumber daya pada Dayak Tamambaloh, merupakan keputusan yang didasarkan pada kosmologi suku ini. Kepercayaan mereka akan alam sebagai hunian roh nenek moyang (animisme) menjadikan mereka "melibatkan" aspek supranatural dalam pengelolaan sumber daya alam. Bagi mereka pemanfaatan dengan cara yang salah, diantaranya akan menimbulkan bencana bahkan kematian. Oleh karena itu, dapat disimpulkan bahwa pemanfaatan sumber daya alam pada Dayak Tamambloh berorientasi pada kebutuhan dasar, bukan pada pasar (market orinted) atau politik ekonomi. Konsep pantang larang dalam pemnafaatan lingkungan dinilai memberikan dapat yang baik bagi lestarinya lingkungan alam Tamambaloh.

Fenomena pantang-larang dalam hubunganya dengan nilai-nilai konservasi ini juga pernah dipaparkan oleh Marvin Harris tetang hubungan simbiotik manusia dan sapi di India (Harris, 1979). Harris berargumen bahwa "eksplanansi mengenai pantangan memakan daging sapi memiliki fungsi positif sebagai proses adaptasi ekologi". Menurut Harris, perlakuan suci terhadap sapi di India membantu melindungi dan melestarikan hubungan simbiotik tersebut. Harris mengamati bahwa sapi di India hanya memberikan sedikit susu meski cukup berarti, akan tetapi kontribusinya yang utama sebagai pemberi bahan bakar dan pupuk yang dihasilkan dari kotoran sapi. Demikian pula, adat istiadat pantanglarang pada Dayak Tamambaloh, menjadi alat kontrol pemanfaatan alam Tamambaloh.

\section{4)Pengetahuan Genetika sebagai Tradisonal Ekologi}

Di dalam masyarakat yang bersahaja, setiap individu untuk hidupnya, perlu memiliki pengetahuan yang pasti tentang lingkungannya, yakni tentang tenaga-tenaga alam, dan tentang tumbuhan serta binatang di sekitarnya yang dimanfaatkan diantaranya untuk pengobatan atau etnomedisin. Dalam beberapa literatur mengemukakan tentang tradisi ekologi masyarakat lokal yang berkaitan tentang pemanfaatan obat tradisional sebagai complementary medicine untuk kesehatan masyarakat Modern. Etnomedis juga bisa secara luas dibagi menjadi dua jenis yaitu. (i) Herbal atau Pengobatan material yaitu pengobatan penyakit atau penyakit yang disebabkan oleh patogen dan gejala alam, serta (ii) Magic-religius dan spiritual, yaitu pengobatan penyakit magis yang disebabkan oleh agen supernatural (Sonowal \& Barua, 2011). Dalam kajian filosofis etnomedis berhubungan erat dengan pengetahuan lingkungan yang di dasari oleh nilai-nilai adat dan spritualis masyarakat lokal (Herlan et al., 
2020). Oleh karena itu masyarakat lokal pada umumnya percaya jika alam merupakan manisfetasi dari "ibu dan perempuan" yang merupakan penjaga yang harus dijaga serta dirawat supaya keseimbangan alam dan ekosistem didalamnya dapat lestari dan memberikan manfaat bagi seluruh mahluk hidup (Lestariningsih \& Wariyatun, 2015). Pengelolaan dan pemanfaatan sumber daya alam, seperti flora dan fauna, yang dilakukan oleh masyarakat lokal, umumnya terintegrasi dengan aspek-aspek sistem sosial dan ekonomi dan telah berhasil dalam melindungi aneka ragam species atau varietas tumbuhan dan hewan (Iskandar, 2017).
Pada ekologi tradisonal Dayak Tamambaloh, pemanfaatan etnomedisin bukan hanya berfokus pada herbal dan tumbuh-tumbuhan tetapi lebih luas lagi merujuk kepada ekosistem dan alam sekitar yang didalamnya terdapat tumbuhan dan hewan. Pemanfaatan tanaman dan hewan sebagai obatobatan merupakan bagian dari pengetahuan genetika etnis ini. Seperti tabel 1. di bawah ini telah diperoleh berdasarkan wawancara dan studi dokumen terkait etnomedisin masyarakat lokal Ketamangungan Tamambaloh sebagai sumber obat sudah sejak turun temurun digukan dan dipercaya oleh masyarakat adat di daerah tersebut.

Tabel 2. Tumbuh dan Hewan sebagai Obat-Obatan

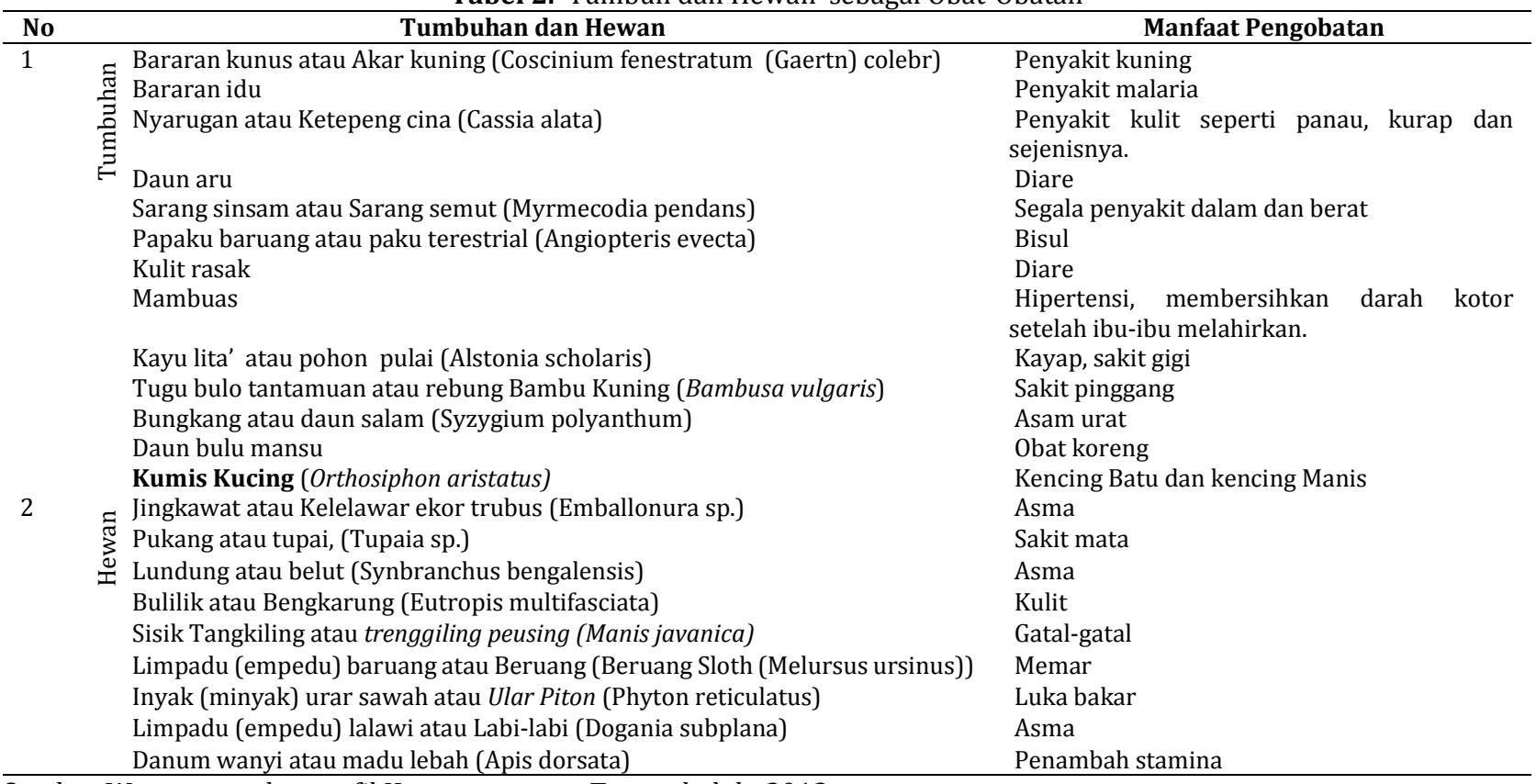

Sumber:Wawancara dan profil Ketamangungan Tamambaloh; 2013

\section{5) Kalender Musim}

Dayak Tamambaloh juga memiliki pembagian waktu atau yang didasarkan pada situasi sekitar. Kalender ini menjadi satu pengetahuan ekologi tradisional komunitas ini. Berikut kalender musim Dayak Tamambaloh.

Kalender musiman ini tidak sama dengan penanggalan yang terdapat pada beberapa suku bangsa di Indonesia. Kalender musiman ini, merupakan rangkuman dari pola aktivitas Dayak Tamambaloh dalam mengelolah lingkungan alam mereka. Kalender musiman ini, merupakan hasil dari rutinitas mereka berinteraksi dengan alam terutama pada aspek pengelolaan dan pemanfaatan. Jika dikaji lebih dalam, kalender musiman ini merupakan pemetaan aktivitas sehari-hari Dayak Tamambaloh yang pada dasarnya didominasi oleh mata pencaharian berladang.

\subsection{Model Konservasi Lingkungan berbasis Ekologi Tradisional Dayak Tamambaloh}

Konservasi alam merupakan upaya melindungi keanekaragaman hayati dan ekosistem untuk generasi mendatang (Schindler et al., 2011). Upaya konservasi alam tersebut dapat mencakup aspek perlindungan, pemeliharaan atau pelestarian dan pemanfaatan secara berkelanjutan, restorasi dan penguatan lingkungan, dalam upaya tercapainya keseimbangan antara kepentingan lingkungan, ekonomi dan sosial budaya masyarakat (Abdoellah, 2012; Iskandar Johan, 2012). Pada prinsipnya, konservasi haruslah memenuhi keseimbangan antara aspek ekonomi, sosial budaya dan lingkungan berkelanjutan (Anup, Rijal, \& Sapkota, 2015). 
Tabel 3. Kalender Musim Dayak Tamambaloh

\begin{tabular}{|c|c|c|c|c|c|c|c|c|c|c|c|c|c|}
\hline \multirow{2}{*}{ No } & \multirow{2}{*}{$\begin{array}{l}\text { Musim/ } \\
\text { Kegiatan }\end{array}$} & \multicolumn{12}{|c|}{ Bulan (Nama Bulan) } \\
\hline & & 1 & 2 & 3 & 4 & 5 & 6 & 7 & 8 & 9 & 10 & 11 & 12 \\
\hline 1. & Hujan & & & & & & & & & $\sqrt{ }$ & $\sqrt{ }$ & $\sqrt{ }$ & $\sqrt{ }$ \\
\hline 2. & Kemarau & & & & & $\sqrt{ }$ & $\sqrt{ }$ & $\sqrt{ }$ & $\sqrt{ }$ & & & & \\
\hline 3. & Banjir & & & & & & & & & & & $\sqrt{ }$ & $\sqrt{ }$ \\
\hline 4. & Kekeringan & & & & & & $\sqrt{ }$ & $\sqrt{ }$ & & & & & \\
\hline 5. & Paceklik & $\sqrt{ }$ & & & & & & & & & & $\sqrt{ }$ & $\sqrt{ }$ \\
\hline 6. & Musim Buah & & & & & & & & & & & $\sqrt{ }$ & \\
\hline 7. & Mencari Lokasi Berladang & & & & & & $\sqrt{ }$ & & & & & & \\
\hline 8. & Menebas Ladang & & & & & & $\sqrt{ }$ & & & & & & \\
\hline 9. & Menebangi Ladang & & & & & & & $\sqrt{ }$ & & & & & \\
\hline 10. & Membakar Ladang & & & & & & & $\sqrt{ }$ & & & & & \\
\hline 11. & Membersihkan & & & & & & & & $\sqrt{ }$ & & & & \\
\hline 12. & Menanam-Menugal & & & & & & & & $\sqrt{ }$ & $\sqrt{ }$ & & & \\
\hline 13. & Penyiangan & & & & & & & & & & $\sqrt{ }$ & $\sqrt{ }$ & \\
\hline 14. & Panen & & $\sqrt{ }$ & $\sqrt{ }$ & & & & & & & & & \\
\hline 15. & Menyadap karet & $\sqrt{ }$ & $\sqrt{ }$ & $\sqrt{ }$ & $\sqrt{ }$ & $\sqrt{ }$ & $\sqrt{ }$ & $\sqrt{ }$ & $\sqrt{ }$ & $\sqrt{ }$ & $\sqrt{ }$ & $\sqrt{ }$ & $\sqrt{ }$ \\
\hline 16. & Mencari rotan & & & & & & $\sqrt{ }$ & & & & & & \\
\hline 17. & Mencari madu & & & & & & & & & & & $\sqrt{ }$ & \\
\hline 18. & Mencari Tengkawang & & $\sqrt{ }$ & & & & & & & & & & \\
\hline 19. & Berburu & $\sqrt{ }$ & $\sqrt{ }$ & $\sqrt{ }$ & $\sqrt{ }$ & $\sqrt{ }$ & $\sqrt{ }$ & $\sqrt{ }$ & $\sqrt{ }$ & $\sqrt{ }$ & $\sqrt{ }$ & $\sqrt{ }$ & $\sqrt{ }$ \\
\hline 20. & Mencari ikan & $\sqrt{ }$ & $\sqrt{ }$ & $\sqrt{ }$ & $\sqrt{ }$ & $\sqrt{ }$ & $\sqrt{ }$ & $\sqrt{ }$ & $\sqrt{ }$ & $\sqrt{ }$ & $\sqrt{ }$ & $\sqrt{ }$ & $\sqrt{ }$ \\
\hline 21. & Ikan bertelur & & & & & & & & & $\sqrt{ }$ & & & \\
\hline 22. & Ikan besar mudik & & & & & & & & & & $\sqrt{ }$ & & \\
\hline 23. & Ikan kecil mudik & & & & & & & $\sqrt{ }$ & & & & & \\
\hline
\end{tabular}

Sumber: Pengamatan dan Profil Ketamangungan Tamambaloh; 2013

Di Indonesia konservasi alam telah dideklarasikan melalui Undang-Undang (No. 5 Tahun 1990), tentang Konservasi Sumber Daya Alam Hayati dan Ekosistemnya, oleh Presiden Republik Indonesia pada 10 Agustus 1990. Konservasi alam tidak saja telah dilakukan secara formal oleh pemerintah, tetapi banyak pula upaya yang telah dilakuan secara mandiri oleh berbagai kelompok masyarakat tradisional atau masyarakat pribumi dengan berbekal pengetahuan lokal dan cukup berhasil (Larson, Cooper, Stedman, Decker, \& Gagnon, 2018; Quan-Baffour, 2018). Oleh karena itu, dalam konservasi, masyarakat lokal memiliki peran yang sangat penting dan dipandang memiliki kemampuan dalam mengelola dan memanfaatkan ekologi secara baik (Kloek, Elands, \& Schouten, 2017).

Pengetahuan ekologi tradisional yang terdapat pada Dayak Tamambaloh, telah menjadi satu bukti nyata keberhasil masyarakat lokal dalam mendukung program-program konservasi lingkungan. Keberhasilan Dayak Tamambaloh dapat kita jumpai dari beranekaragamnya primata seperti Kelampiau (Hylobates muellen), Orang Utan (Pongo pygmaeus), Beruk (Macaca nemestrina), Kera (Macaca fascicularis), Kukang (Nycticebus coucang), Tarsius (Tarsius bancanus) Babi (Sus sp); berbagai jenis burung-burung seperti Pecuk Ular, Raja Udang dan Enggang Gading (Buceros vigil), Enggang Badak (Buceros rhinoceros); berbagai jenis mamalia seperti Kucing Hutan (Felis bengalensis), Kijang Emas (Muntiacus atherodes), Rusa Sambar (Cerves sp) dan Kancil (Tragulus napu); berbagai jenis ikan, seperti jelawat (Leptobarbus hoeveni), belut (Synbranchus bengalensis) dan Semah (Tor tambroides); berbagai reptilia seperti ular sanca (Python reticulatus), bengkarung (Eutropis multifasciata), lakian (Draco volans), biawak (Varanus salvator), labi-labi (Dogania subplana), buaya (Crocodylus sp.) dan ular sinduk (Naja sputatrix); berbagai jenis serangga, dan amphibi, serta berbagai jenis tumbuhan seperti berbagai jenis Anggrek, berbagai jenis pohon (Taman Nasional Betung Kerihun, 2009), serta berbagai jenis tumbuhan obat-obatan tradisional yang berpotensi sebagai bahan baku berbagai obat baru (Herlan et al., 2020).

Dalam ekologi tradisionalnya yang sekurangkuranganya terdiri dari 1) pembagian kawasan adat berdasarkan peruntukannya, dan berdasarkan akses sumber daya, 2) Aturan akses sumber daya alam, 3) Pantang-larang dalam pengelolaan Lingkungan alam, 4) Pengetahuan Gentika (etnomedisin), dan 5) Kalender Musim, Dayak Tamambaloh telah mengembangkan 4 model konservasi alam.

1. Model Environmental Norms

Terdapat pengaturan sumber daya (Norma Lingkungan). Norma lingkungan dikembangkan dalam pembagian kawasan, peruntukan kawasan, aturan akses sumber daya dan kalender musiman. Norma lingkungan ini menjadi pedoman bagi Dayak Tamambaloh dalam melakukan tindakan yang berujung pada konservasi lingkungan.

2. Model Proenvironmental Behavior dan Environmental Concern

Kelestarian lingkungan pada kawasan ketamanggungan Tamambaloh merupakan andil dari seluruh orang Tamambaloh yang memiliki sikap peduli lingkungan (pro-lingkungan). Kepedulian lingkungan (Environmental Concern) menjadikan orang-orang Dayak Tamambaloh mengelola dan memanfaatan lingkungan mengacuh pada konsep kelestarian lingkungan. 
3. Model Community Involvemen

Seluruh anggota Katamanggungan Tamambaloh terlibat aktiv dalam pemanfaatan dan pengelolaan lingkungan berbasikan norma-norma yang telah disepakati bersama.

4. Model Enviromental Dicision

Dayak Tammabloh mengembangkan enviromental Dicision yang bersifat komunal yang berbasiskan pada tradisi pantang-larang yang merupakan bagian dari kosmologi tradisional. Keputusan dalam pemanfaatan sumber daya alam, dilakukan pada level individu dan juga komunal, yang berorientasi pada pemenuhan kebutuhan dasar.

\section{Kesimpulan}

Ekologi tradisional merupakan pengetahuan tentang lingkungan dan alam sekitar yang berkembang dan dikembangkan secara turuntemurun oleh masyarakt lokal. Ekologi tradisional merupakan satu kearifan lokal yang mengandung nilai-nilai konservasi lingkungan yang berkelanjutan. Pengelolaan dan pemanfaatan sumber daya pada masyarakat lokal dilakukan berdasarkan pengetahuan lokal.

Nilai-nilai konservatif pada ekologi tradisional terdapat dalam beberapa bentuk, diantaranya seperti yang terdapat dalam ekologi tadisional Dayak Tamambaloh, yakni Environmental Norms, Proenvironmental Behavior dan Environmental Concern, Community Involvemen dan enviromental Dicision. Dalam ekologi tradisional umumnya terdapat norma-norma yang menjadi pedoman dalam pemanfaatan dan akses sumber daya. Norma-norma tersebut berisi aturan berupa larangan dan sanksi atas pelanggaran terhadap aturan. Setiap anggota masyarakat atau anggota etnis, terlibat secara aktif dalam norma-norma tersebut. Norma tersebut merupakan pengalaman bersama, hasil dari proses etnis tersebut dalam beinteraksi dengan alam. Pola ketergantungan terhadap alam, menjadi masyarakat lokal mengembangan perilaku yang pro lingkungan dan mereka sangat peduli dengan lingkungan alam.

Kelestarian lingkungan pada masyarakat lokal seakan-akan bukan merupakan sesuatu yang diusahakan atau diprogramkan, karena kelestarian lingkungan menjadi bagian yang terintegrasi secara langsung dengan kehidupan sehari-hari masyarakat lokal. Konsep-konsep kelestarian lingkungan telah terinternalisasi dalam sertiap orang, karenanya ekologi tradisonal merupakan kebudayaan.

\section{DAFTAR PUSTAKA}

Abdoellah, O. S. (2012). Antropologi Ekologi; Konsep, Teori dan Aplikasi dalam Konteks Pembangunan Berkelanjutan. Bandung: AIPI, Puslitbang KPK LPPM Unpad dan M63 Foundation.

Agrawal, A. (2014). Indigenous and Scientific Knowledge: Some Critical Comments. Antropologi Indonesia, 0(55). https://doi.org/10.7454/ai.v0i55.3331
Al-Fattal, R. (2009). The tragedy of the commons: Institutions and fisheries management at the local and EU levels. Review of Political Economy, 21(4), 537547. https://doi.org/10.1080/09538250903214834

Anbleyth-Evans, J., Lacy, S. N., Aguirre-Muñoz, C., \& Tredinnick-Rowe, J. (2020). Port dumping and participation in England: Developing an ecosystem approach through local ecological knowledge. Ocean and Coastal Management, 192(April 2019). https://doi.org/10.1016/j.ocecoaman.2020.105195

Anup, K. C., Rijal, K., \& Sapkota, R. P. (2015). Role of ecotourism in environmental conservation and socioeconomic development in Annapurna conservation area, Nepal. International Journal of Sustainable Development and World Ecology, 22(3), 251-258. https://doi.org/10.1080/13504509.2015.1005721

Aziz Nasihuddin, A. (2017). Kearifan Lokal Dalam Perlindungan Dan Pengelolaan Lingkungan Hidup ( Studi Di Desa Janggolan Kec. Sumpiuh, Banyumas). Bina Hukum Lingkungan, 2(1), 99-107. https://doi.org/10.24970/jbhl.v2n1.9

Baharudin, E. (2012). Kearifan Lokal, Pengetahuan Lokal dan Degradasi Lingkungan (pp. 1-13). pp. 1-13. Universitas Esa Unggul.

Barbieri, C., \& Aguilar, F. X. (2011). The Ius in Re Model to Analyze Users Rights Within Complex Property Regimes: Two Ex Post Applications in South America. Society and Natural Resources, 24(3), 292-302. https://doi.org/10.1080/08941920903278178

Berkes, F. (1993). Traditional Ecological Knowledge in Perspective. In J. T. Inglis (Ed.), Traditional EcologicalKnowledge: Concepts and Cases (pp.1-10). https://doi.org/10.1007/978-3-030-22944-3_13

Berkes, F. (2008). Sacred Ecology (Second Edi). New York: Routledge.

Boafo, Y. A., Saito, O., Kato, S., Kamiyama, C., Takeuchi, K., \& Nakahara, M. (2016). The role of traditional ecological knowledge in ecosystem services management: the case of four rural communities in Northern Ghana. International Journal of Biodiversity Science, Ecosystem Services and Management, 12(1-2), 24-38. https://doi.org/10.1080/21513732.2015.1124454

Bromley, D. W., \& Cernea, M. M. (1989). The management of common property natural resources. In Human Ecology (Vol. https://doi.org/10.1007/BF01047654

Daeng, H. J. (2008). Manusia, Kebudayan dan Lingkungan: Tinjauan Antropologis. Yogyakarta: Pustaka Pelajar.

Docherty, M. (2016). Environmental Decision-Making (G. Hanne, Ed.). e Advanced Technology Environmental and Energy Center (ATEEC).

Efriani, Gunawan, B., \& Judistira, K. G. (2019). Kosmologi dan Konservasi Alam pada Komunitas Dayak Tamambaloh di Kalimantan Barat. Studi Desain, 2(2), 66-74.

Erawati, E. (2016). Traditional Settlement Patterns of Kajang. Kapata Arkeologi, 12(2), 147-162.

Ferrante, L., Gomes, M., \& Fearnside, P. M. (2020). Amazonian indigenous peoples are threatened by Brazil's Highway BR-319. Land Use Policy, 94(October 2019), 104548. https://doi.org/10.1016/j.landusepol.2020.104548

Ford, J. D., King, N., Galappaththi, E. K., Pearce, T., McDowell, G., \& Harper, S. L. (2020). The Resilience of Indigenous Peoples to Environmental Change. One Earth, 2(6), 532-543. https://doi.org/10.1016/j.oneear.2020.05.014 
Grim, J. A. (2001). Deep Ecology And World Religions New Essays On Sacred Grounds. In D. L. B. R. S. Gottlieb (Ed.), Deep Ecology and World Religions : New Essays on Sacred Grounds (pp. 35-58). New York: State University Of New York.

Harris, M. (1979). Cultural Materialism: The Struggle for a Science of Culture. New York: Random House.

Herlan, Praptantya, D. B., Juliansyah, V., Efriani, \& Dewantara, J. A. (2020). Konsep sehat dan sakit pada Budaya Etnis Dayak Kebahan. Etno, 9(1), 24-38. https://doi.org/https://doi.org/10.33772/etnoreflik a.v9i1.720

Iskandar, J. (2017). Etnobiologi dan Keragaman Budaya di Indonesia. Indonesian Journal of Anthropology, 1(1), 27-42. https://doi.org/10.24198/umbara.v1i1.9602

Iskandar, J., \& Iskandar, B. Su. (2016). Etnoekologi dan Pengelolaan Agroekosistem oleh Penduduk Desa Karangwangi Kecamatan Cidaun, Cianjur Selatan Jawa Barat. Jurnal Biodjati, 1(1), 1. https://doi.org/10.15575/biodjati.v1i1.1035

Iskandar Johan. (2012). Etnobiologi dan Pembangunan Berkelanjutan. Bandung: AIPI Bandung, Puslitbang KPK LPPM Unpad Bandung dan M63 Foundation.

Kakoty, S. (2018). Ecology, sustainability and traditional wisdom. Journal of Cleaner Production, 172, 32153224. https://doi.org/10.1016/j.jclepro.2017.11.036

Kalland, A. (2005). Indigenous Knowledge: Prospects And Limitations. In A. Ellen, Roy. Parkes, Peter dan Bicker (Ed.), Indigenous Environmental Knowledge and its Transformations: Critical Anthropological Perspectives (pp. 316-331). Taylor and Francis.

Kloek, M. E., Elands, B. H. M., \& Schouten, M. G. C. (2017). Race/Ethnicity in Visual Imagery of Dutch Nature Conservation Organizations. Society and Natural Resources, 30(9), 1033-1048. https://doi.org/10.1080/08941920.2017.1295500

Larson, L. R., Cooper, C. B., Stedman, R. C., Decker, D. J., \& Gagnon, R. J. (2018). Place-Based Pathways to Proenvironmental Behavior: Empirical Evidence for a Conservation-Recreation Model. Society and Natural Resources, 31(8), 871-891. https://doi.org/10.1080/08941920.2018.1447714

Laughlin, C. D. (2013). Consciousness and the commons: A cultural neurophenomenology of mind states, landscapes, and common property. Time and Mind, $6(3)$, 287-312. https://doi.org/10.2752/175169713X13673499387 046

Lestariningsih, D., \& Wariyatun. (2015). "nDuweni Ibu Pertiwi"(Keeping the motherland): Women's agency to resist cement plants in Tegaldowo and Timbrangan villages, Rembang. Asian Journal of Women's Studies, 21(2), 166-179. https://doi.org/10.1080/12259276.2015.1062271

Messalina Lovenia Salampessy, Indra Gumay Febryano, \& Iskar Bone. (2017). Pengetahuan ekologi Masyarakat Lokal dalam pemilihan Pohon Pelindung Padasistem Agroforestri Tradisional "Dusung" Pala di Ambon. Jurnal Penelitian Sosial Ekonomi Kehutanan, 14(2), 135-142.

https://doi.org/http://dx.doi.org/10.20886/jpse.20 17.14.2.135-142

Nurani, C. (2015). Kearifan Lingkungan dalam Pengelolaan Hutan, Tanah dan Sungai di Desa Singengu, Kecamatan Kotanopan Kabupaten Mandailing Natal, Sumatera Utara. Jurnal Manusia Dan Lingkungan, 22(1), 100-105.
Paroki Santo Martinus. (2013). Buku Kenangan 100 Tahun Paroki ST. Martinus. Banua Martinus: Paroki St. Martinus.

Patriana, R., Adiwibowo, S., Kinseng, R. a, \& Satria, A. (2016). Perubahan Kelembagaan dalam Pengelolaan Sumberdaya Laut Tradisional ( Kasus Kelembagaan Sasi Di Kaimana ). Sodality: Jurnal Sosiologi Pedesaan, 4(3), 257-264.

Posey, D. A. (2005). Ethnobiology and Ethnoecology in the Context of National Laws and International Agreements Affecting Indigenous and Local Knowledge, Traditional Resources and Intellectual Property Rights. In R. Ellen, P. Parkes, \& A. Bicker (Eds.), Indigenous Environmental Knowledge and its Transformations Critical Anthropological Perspectives (pp. 32-55). Australia • Canada • France - Germany • India Japan • Luxembourg • Malaysia • The Netherlands Russia - Singapore - Switzerland: harwood academic publishers.

Quan-Baffour, K. P. (2018). A Systemic View of the Value of Environmental Conservation: The Case of Bono Takyiman, Ghana. In J. McIntyre-Mills, N. Romm, \& Y. Corcoran-Nantes (Eds.), Contemporary Systems Thinking Balancing Individualism and Collectivism Social and Environmental Justice (pp. 211-220). Retrieved from https://link.springer.com/content/pdf/10.1007\%2F 978-3-319-58014-2.pdf

Rusmana, A., Edwin Rizal, Khadih, U. L., \& Anwar, R. K. (2017). Pengembangan Kelembagaan Tradisional Masyarakat Daerah Sebagai Penyangga Hutan Untuk Pelestarian Taman Nasional Gunung Halimun Salak ( Tnghs ). JISPO, 1(Januari-Juni), 50-73. https://doi.org/10.15575/jp.v7i1.1736

Schindler, S., Cimadom, A., \& Wrbka, T. (2011). The attitude towards nature and nature conservation on the urban fringes. Innovation, 24(3), 379-390. https://doi.org/10.1080/13511610.2011.596700

Seftyono, C. (2011). Pengetahuan Ekologi Tradisional Masyarakat Orang Asli Jakun dalam Menilai Ekosistem Servis di Tasik Chini, Malaysia. JSP: Jurnal Ilmu Sosial Dan Ilmu Politik, 15(1), 55-67. https://doi.org/10.22146/jsp.10925

Setyawan, A. D. W. I. (2010). Dayak Conservation knowledge(2010).pdf. Bioscience, 2(2), 97-108.

Siahaya, M. E., Hutauruk, T. R., Aponno, H. S. E. S., Hatulesila, J. W., \& Mardhanie, A. B. (2016). Traditional ecological knowledge on shifting cultivation and forest management in East Borneo, Indonesia. International Journal of Biodiversity Science, Ecosystem Services and Management, 12(1-2), 14-23. https://doi.org/10.1080/21513732.2016.1169559

Sick, D. (2008). Social contexts and consequences of institutional change in common-pool resource management. Society and Natural Resources, 21(2), 94-105. https://doi.org/10.1080/08941920701681524

Singh, N. (2006). Indigenous water management systems: Interpreting symbolic dimensions in common property resource regimes. Society and Natural Resources, 19(4), 357-366. https://doi.org/10.1080/08941920500519297

Siswadi, S., Taruna, T., \& Purnaweni, H. (2012). KEARIFAN LOKAL DALAM MELESTARIKAN MATA AIR (Studi Kasus di Desa Purwogondo, Kecamatan Boja, Kabupaten Kendal). Jurnal Ilmu Lingkungan, 9(2), 63. https://doi.org/10.14710/jil.9.2.63-68 
Sonowal, R., \& Barua, I. (2011). Ethnomedical practices among the Tai-Khamyangs of Assam, India. Studies on Ethno-Medicine, $5(1)$ 41-50. https://doi.org/10.1080/09735070.2011.11886390

Sumunar, D. R. S., Suparmini, \& Setyawati, S. (2017). Masyarakat desa Tenganan Pegringsingan. Jurnal Penelitian Humaniora, 22(2), 111-124.

Suradisastra, K. (2011). Membangkitkan ketangguhan sosial dan ekologi. Pusat Analisis Sosial Ekonomi Dan Kebijakan Pertanian Bogor.

Taman Nasional Betung Kerihun. (2009). Buku Informasi Taman Nasional Betung Kerihun. Putussibau: Balai Besar Taman Nasional Betung Kerihun.

Uprety, Y., Asselin, H., Bergeron, Y., Doyon, F., \& Boucher, J. F. (2012). Contribution of traditional knowledge to ecological restoration: Practices and applications. Ecoscience, 19(3), 225-237. https://doi.org/10.2980/19-3-3530

Wiersum, K. F., Singhal, R., \& Benneker, C. (2004). Common property and collaborative forest management: Rural dynamics and evolution in community forestry regimes. Forests Trees and Livelihoods, 14(2-4), 281293.

https://doi.org/10.1080/14728028.2004.9752498

Yuliani, E. L., Adnan, H., Sunderland, R. A., Bakara, D., Heri, V., Sammy, J., \& Terry, A. salim; (2018). The roles of traditional knowledge systems in orang-utan Pongo spp. and forest conservation: a case study of Danau Sentarum, West Kalimantan, Indonesia. 52(1), 156165. https://doi.org/10.1017/S0030605316000636 